\title{
THE SPEED AND STABILITY OF PRICE ADJUSTMENT IN AUSTRALIAN MANUFACTURING
}

By Harry Bloch and Michael Olive*

\begin{abstract}
A model of industry speed of price adjustment is derived from firm pricing behaviours. The model is applied to quarterly two-digit Australian manufacturing data for the period $1985: 3$ to $2002: 3$. Initially, the industry speed of price adjustment is treated as a function of structural cross-section variables. The results suggest that the industry speed of price adjustment is positively related to the average size of large firms within the industry and is negatively related to industry concentration. With the inclusion of time variables into the final estimating equation, we find that import share has a role in attenuating the effects of industry concentration and that trend real GDP growth reduces the speed of price adjustment. While a 1990s dummy variable is included in the final estimating equation and is found to be significant, its magnitude is too small to be of economic importance. Calculated industry speeds of price adjustment are stable across the period of examination but are also small, suggesting that manufacturing prices are sticky.
\end{abstract}

*Email: molive@efs.mq.edu.au 


\section{Introduction}

An outstanding recent feature of many economies has been the dramatic slow down in inflation. To underline the importance of this development, Taylor (2000, p1389) says "examining the causes and consequences of the period of price stability that began in many countries in the 1980s or early 1990s is as useful for future policy making as examining the Great Depression of the 1930s or the Great Inflation of the late 1960s and 1970s”. Australia has been no exception to this change in pricing behaviour, with an average quarterly total manufacturing price change of: 2.3 percent in the period 1969:4 to $1985: 2 ; 1.5$ percent in the period $1985: 3$ to $1990: 4$; and 0.5 percent in the period 1991:1 to 2002:2 (Australian Bureau of Statistics, 6437.0, Table 10).

There are various explanations for such a benign inflationary outcome that range from structural change to changes in firm expectations to favourable shocks to prices (see Dwyer and Leong, 2001; Taylor, 2000). An approach taken by Dwyer and Leong (2001) is to determine whether evidence of a structural break in the speed of price adjustment for Australian consumer prices exists. Based on recursive point estimates, they suggest that the speed of price adjustment has been slow and fairly stable through the 1990s. The authors admit, however, that there is room for a different interpretation of their Figure 13 as a fall in the speed of price adjustment is possible within their confidence intervals.

Macroeconomic models regularly emphasise the importance of the speed of price adjustment in determining real and nominal aggregates. New Keynesian models suggest that strong quantity adjustments and slow price adjustments in response to demand shocks are key to understanding business cycles. Depending on the interactions with other sectors of the economy, the speed of price adjustment may additionally impact on the long-run inflation rate. It is also suggested that exchange 
rates can overshoot if domestic interest rates are out of alignment with world interest rates and prices are sticky.

In this paper, we are concerned with the speed and stability of price adjustment to its long-run value. Our approach is to estimate the determinants of the speed of price adjustment in Australian manufacturing industries and see whether these have shifted over time. This contrasts with the common practice in previous studies of estimating the industry speed of price adjustment as a function of structural variables that are deemed not to vary across time, most particularly industry concentration (for example see Domberger (1983); Dixon (1983); Bedrossian and Moschos (1988); Kardasz and Stollery (1988); Weiss (1993); Shannan and Feinberg (1995). An exception is Kraft (1995) who estimates the industry speed of price adjustment as a function of a dichotomous cycle variable, inter alia.

In a theory paper, Martin (1993) incorporates quadratic price adjustment costs into the profit equation and derives the speed of price adjustment as a negative function of market power. Implicit in Martin's formulation is that the speed of price adjustment is also a function of firm size, although he does not explore this issue. Indeed, there are only isolated references in the literature that posit a relationship between firm size and the speed of price adjustment. In a recent study of Swedish firms, Apel et al (2005) find that the number of price changes per year is positively related to firm size but negatively related to industry concentration. It is also suggested by Domberger (1983) that large firms have large profit cushions and, as a result, are less risk averse, leading to faster speeds of price adjustment. A natural extension of this argument is that firms have economies of scale over certain implicit adjustment costs. 
In Section 2, we present a model of firm behaviour in which the speed of price adjustment is a function of market power and firm size. Averaging across all firms in an industry transforms the pricing model into an error-correction form, which places fewer restrictions on the short-run dynamics of the estimating equation when compared to a partial adjustment model.

In Section 3, the model is applied to quarterly two-digit Australian manufacturing data for the period 1985:3 to 2002:3. Initially, the industry speed of price adjustment is treated as a function of structural cross-section variables. The results suggest that the industry speed of price adjustment is positively related to the average size of large firms within the industry and is negatively related to industry concentration. With the inclusion of time variables into the final estimating equation, we find that import share has a role in attenuating the effects of industry concentration and that trend real GDP growth reduces the speed of price adjustment. While a 1990s dummy variable is included in the final estimating equation and is found to be significant, its magnitude is too small to be of economic importance. Calculated industry speeds of price adjustment are stable across the period of examination but are also small, suggesting that manufacturing prices are sticky.

Section 4 discusses the implications of results and their importance for economic policy.

\section{The model}

Consider an imperfectly competitive industry that consists of $N$ firms, each producing a differentiated product. Let the short-run profit function of the $i^{\text {th }}$ firm be:

$$
\pi\left(p_{i t}\right)=\left(p_{i t}-m c_{i t}\right) q_{i t}-\alpha_{i}\left(\frac{p_{i t}-p_{i t-1}}{p_{i t-1}}\right)^{2}\left(q_{i t}^{*}\right)^{S}
$$


where $i$ and $t$ represent firm and time subscripts, respectively, and $p_{i t}, q_{i t}, q_{i t}^{*}, m c_{i t}$, $\alpha_{i}$ and $S$ indicate price, output, target output, constant marginal cost (excluding adjustment costs), a cost of adjustment parameter and an economies of scale parameter, respectively. It can be seen that the first term on the right-hand side of (1) is revenue minus non-adjustment related costs, while the second term on this side is the cost of price adjustment. ${ }^{1}$

When $S$ is zero, the cost of price adjustment in (1) is the standard quadratic price adjustment cost function. This implies larger imposts on the firm for larger percentage price changes. Rotemberg (1982a, 1982b) cites unfavourable customer reaction to higher prices as an example of this type of cost. Presumably, the firm imputes a value to the loss of current and future goodwill when prices are raised to levels above expectations or when prices are increased well in advance of competitor prices. In a similar but alternative scenario, firms uncertain about market conditions may be unsure ex ante that a given target price is optimal and so impute a cost to rapid price change (for a discussion, see Domberger; 1983, pp 54-59).

Adjustment costs can also arise in input markets, with many authors pointing to turnover costs in relation to labour (see Kraft, 1995; Kasa, 1998; and Lindbeck and Snower, 2001). Given the rationing role of prices, it seems reasonable to model these adjustment costs in the form of quadratic price adjustments under certain conditions. In this paper, the quadratic price adjustment cost function is interpreted as representing an amalgam of implicit costs that can arise from adjustments in both product and input markets.

With the standard quadratic price adjustment cost function, the implicit cost to the firm of a given proportional price change remains the same regardless of firm size.

\footnotetext{
${ }^{1}$ Zero fixed costs are assumed for simplicity. This does not affect the analysis.
} 
Therefore, the absolute value of the cost of price adjustment would be the same for a large multinational company as for a local artisan (given the same $\alpha_{i}$ ). This only makes sense if there are extreme economies of scale. In order to allow for varying scale effects, the price adjustment cost is also a function of the firm's target output level. For a given price adjustment, it can be seen from (1) that the average cost of price adjustment declines with target output (economies of scale) when $S$ is less than one; that it increases with target output (diseconomies of scale) when $S$ is greater than one; and that it is constant when $S$ is equal to one.

In the absence of adjustment costs, the first-order condition for profit maximisation is as follows:

$q_{i t}^{*}+\left(p_{i t}^{*}-m c_{i t}\right)\left(d q_{i t}^{*} / d p_{i t}^{*}\right)=0$

where * indicates the static equilibrium values of price, output and the slope of the demand function. When adjustment costs are taken into consideration, $q_{i t}^{*}$ and $p_{i t}^{*}$ become the firm's target output and target price, respectively (this assumption is standard in the literature e.g. Roberts, 1992; Martin, 1993). Given that the actual price and the target price differ, firm output can be approximated using the following firstorder Taylor series:

$q_{i t} \approx q_{i t}^{*}+\left(d q_{i t}^{*} / d p_{i t}^{*}\right)\left(p_{i t}-p_{i t}^{*}\right)$

Substituting (3) into (1) explicitly expresses profit as a function of price. After imposing the first-order profit maximising condition and incorporating (2) into the analysis, the firm chooses to change prices according to the following model: 


$$
\begin{aligned}
& \Delta p_{i t}=\lambda_{i t}\left(p_{i t}^{*}-p_{i t-1}\right) \\
& \lambda_{i t}=\left[1-\left(\frac{\alpha_{i} \beta_{i t}}{\eta_{i t} p_{i t}^{*} q_{i t}^{* 1-S}}\right)\right]^{-1} \\
& \eta_{i t}=\frac{p_{i t}^{*}}{q_{i t}^{*}} \frac{d q_{i t}^{*}}{d p_{i t}^{*}}
\end{aligned}
$$

where $\Delta p_{i t}=p_{i t}-p_{i t-1}, \lambda_{i t}$ is the speed of price adjustment, $\eta_{i t}$ is the elasticity of demand and $\beta_{i t}=\left(p_{i t}^{*} / p_{i t-1}\right)^{2}$. It is readily apparent that the range of $\lambda_{i t}$ is from zero to one and that (4) is a partial adjustment model. Holding other things constant, it can be seen from (5) that the firm's speed of price adjustment increases/decreases with target output when the firm has economies/diseconomies of scale with respect to the costs of price adjustment. Also, the speed of price adjustment increases with firm revenue when $S$ is zero. Finally, as demand becomes more/less elastic the firm's speed of price adjustment increases/decreases. It should be noted from (4) that the determinants of the speed of price adjustment are identical when prices are in natural logarithms and price changes are relatively small. ${ }^{2}$

In order to give further direction to the empirical analysis in this paper, it is necessary to aggregate firm effects across the industry. Taking a weighted average of (4) across all firms in the industry and manipulating gives the following errorcorrection model:

$$
\Delta p_{d t}=\gamma_{d t} \Delta p_{d t}^{*}-\lambda_{d t}\left(p_{d t-1}-\delta_{d t} p_{d t-1}^{*}\right)
$$

\footnotetext{
${ }^{2}$ For small changes, $\Delta p_{i t} / p_{i t-1} \approx \ln p_{i t}-\ln p_{i t-1}$ and $\left(p_{i t}^{*}-p_{i t-1}\right) / p_{i t-1} \approx \ln p_{i t}^{*}-\ln p_{i t-1}$.
} 
where $d$ is an industry subscript and $\Delta p_{d t}=\sum w_{i} \Delta p_{i t}, \Delta p_{d t}^{*}=\sum w_{i} \Delta p_{i t}^{*}$,

$p_{d t-1}=\sum w_{i} p_{i t-1}, p_{d t-1}^{*}=\sum w_{i} p_{i t-1}^{*}, \gamma_{d t}=\left(\frac{\sum w_{i} p_{i t}^{*} \lambda_{i t}}{\sum w_{i} p_{i t}^{*}}\right), \lambda_{d t}=\left(\frac{\sum w_{i} p_{i t-1} \lambda_{i t}}{\sum w_{i} p_{i t-1}}\right)$ and

$\delta_{d t}=\gamma_{d t} / \lambda_{d t}$. Here, $w_{i}$ represents the $i^{\text {th }}$ firm's share of the value of industry

shipments at a point in time, so that the industry prices and target prices given in (7)

are share-weighted averages. The error-correction form of the model comes about

because $\gamma_{d t}$ and the industry speed of price adjustment $\left(\lambda_{d t}\right)$ are differently weighted averages of each firm's speed of price adjustment. ${ }^{3}$ If all firms in the industry have the same speed of price adjustment, then the industry model reverts to the partial adjustment form.

\section{Data and empirical model}

In this section we examine the determinants and stability of the industry speed of price adjustment for nine Australian manufacturing industries at the two-digit level during the period 1985:3 to 2002:3. Two-digit industries are examined because many quarterly data series employed in this study do not exist at a lower level of aggregation. Further, the Australian Bureau of Statistics (ABS) switched to the Australian and New Zealand Standard Industry Classification (ANZSIC) in the early 1990s, making it difficult to extend particular data series beyond this time period. For this reason, total manufacturing average weekly earnings is employed as a proxy for industry average weekly earnings in what follows. See the Data Appendix for a full description of the data series and sources.

\footnotetext{
${ }^{3}$ This method for obtaining an error correction model could be contrasted with those outlined by Nickell (1985).
} 
O’Regan and Wilkinson (1997) estimate the long-run elasticity of domestic industry price with respect to import price for 30 Australian manufacturing industries over the period 1983:2 to 1995:2 and find it significantly greater than zero in nearly every case. As the authors point out, cost and other demand shift variables are not included in the model, so the results may be overstated. Bloch and Olive (1999) estimate a pricing equation for 89 Australian manufacturing industries over the period $1971 / 72$ to $1984 / 85$. While they generally find that unit cost is the dominant influence on industry price, competing foreign price and manufacturing price are influential in highly concentrated industries exposed to foreign competition and aggregate output is influential in highly concentrated industries with low exposure to foreign competition.

These studies suggest that industry price is likely to be a function of both demand and cost variables. In this study, industry target price is modelled as a linear function of industry materials price $\left(m p_{d t}\right)$, average weekly earnings $\left(w_{t}\right)$, import price $\left(i m p_{d t}\right)$, aggregate manufacturing price $\left(p m_{t}\right)$ and trend real GDP $\left(y_{t}\right)$ [the $d$ subscript is dropped where the variable is common to all industry target prices].

With reference to Equations (5) and (7), industry speed of price adjustment is modelled as a linear function of average firm size and variables that are likely to affect the industry elasticity of demand. In the first instance, we look at the influence on the speed of price adjustment of structural variables that change across industry, but not (rapidly) across time.

Numerous studies in the structure-conduct-performance tradition find statistically positive relationships between industry concentration and price-cost margins (for a review, see Lipczynski et al, 2005). With regard to heterogeneous goods, Sawyer (1982) suggests that industry concentration may act on firm price conjectures, inter alia, to make demand less elastic and increase margins. Following 
this reasoning, it is expected that an increase in industry concentration reduces the industry speed of price adjustment.

Previous studies suggest that Australian industry concentration changes only slowly over time. Dixon (1987) shows that the four-firm concentration ratio averages a 4.3 percent change across 101 Australian manufacturing industries between 1968 and 1982, while Bhattacharya and Bloch (2000) find that industry concentration adjusts by 10 percent per year toward its long-run equilibrium value. The four-firm concentration ratio is only available from ABS in selected years. With slow adjustment, however, using industry values for one year (1993-94) should not affect the empirical analysis.

Given economies of scale with regard to price adjustment costs, it is expected that average firm output positively influences industry speed of price adjustment. Here, turnover averaged across the four largest firms within an industry for 1993-94 is used to represent average firm output. This seems reasonable, as the largest firms are likely to have the greatest weights in (7). Firm size is also treated as a cross-sectional variable due to the lack of data availability. However, as large firm size is generally highly correlated with concentration within an industry, but not necessarily across industries, this seems a reasonable approximation. ${ }^{4}$

Given the error-correction model developed in Section 2, the basic empirical pricing equation for each industry is of the form:

$$
\begin{aligned}
\Delta p_{d t}= & \theta_{d 1}+\theta_{d 2} \Delta m p_{d t}+\theta_{d 3} \Delta w_{t}+\theta_{d 4} \Delta i m p_{d t}+\theta_{d 5} \Delta p m_{t}+\theta_{d 6} \Delta y_{t} \\
& -\lambda_{d} E C M_{d t-1}+\varepsilon_{d t}
\end{aligned}
$$

\footnotetext{
${ }^{4}$ The authors correlate the real turnovers for the largest four firms with the four-firm concentration ratio for 12 two-digit ASIC industries between 1968-69 and 1991-92. In nine industries the correlation value is over 0.75 and for seven industries it is over 0.90 . However, this contrasts with the crosssectional correlation for 1993-94 for two-digit ANSIC data, which is only 0.42.
} 


$$
\begin{aligned}
& E C M_{d t-1}=p_{d t-1}-\phi_{d 2} m p_{d t-1}-\phi_{d 3} w_{t-1}-\phi_{d 4} i m p_{d t-1}-\phi_{d 5} p m_{t-1}-\phi_{d 6} y_{t-1} \\
& \lambda_{d}=\left(\ell_{1}+\ell_{2} C R 4_{d}+\ell_{3} S I Z 4_{d}\right)
\end{aligned}
$$

where $\Delta$ indicates first difference, $\theta_{d 1}$ to $\theta_{d 6}$ and $\phi_{d 2}$ to $\phi_{d 6}$ and $l_{1}$ to $l_{3}$ are parameters, $E C M_{d t-1}$ is the error-correction mechanism, and $\varepsilon_{d t}$ is an error term. ${ }^{5}$ Initially, the industry speed of price adjustment $\left(\lambda_{d}\right)$ is modelled as a function of the four firm concentration ratio $\left(C R 4_{d}\right)$ and the average firm turnover of the four largest firms within each industry $\left(S I Z 4_{d}\right)$. The parameters $l_{1}$ to $l_{3}$ are constrained to be the same for each industry, so that $\lambda_{d}$ varies across industries but not across time.

Because industry price is in index form, a problem exists in determining the speed of price adjustment using seemingly unrelated regression or fixed effects estimation with cross-sectional constraints. Taking an industry price index to be the true price multiplied by an unknown number that can only change across industries, estimating (8) for any one industry will result in an unbiased estimate of the speed of price adjustment. This is because industry price and its lagged value are multiplied by the same unknown number. However, constraining the speed of price adjustment across industries via (10) is likely to introduce a bias into the estimates of $\lambda_{d}$ unless the unknown number does not change across industries. As an alternative, the model

\footnotetext{
${ }^{5}$ The error term in (8) can be justified in a number of ways. At the level of the firm, a stochastic error term could be added to (3) to suggest some uncertainty in demand once the price is set. Alternatively, the change in profit with respect to a marginal change in firm price could be stochastic with an expected value of zero if firms are uncertain as to the profit maximising price. The outcome is the same in both of these cases. The term $v_{i t} f\left(\alpha_{i}, q_{i t}^{* S}, p_{i t-1}, d q_{i t}^{*} / d p_{i t}^{*}\right)$ is added to the firm partial adjustment model shown in (4), where $v_{i t}$ is stochastic and has an expected value of zero. This suggests that the error term in (8) has an expected value of zero and is independent of other right hand side variables but that heterogeneity exists.
} 
is estimated with the time-varying series transformed into natural logarithms, which results in unbiased estimates of $\lambda_{d}{ }^{6}$

In order to determine whether our model is statistically adequate, the timeseries properties of the data are investigated, with the results presented in Table 1 . The Im, Pesaran and Shin (2003) test for unit roots in panel data indicates that the natural logarithm of domestic industry price, industry materials price and import price each have a unit root in levels but are first-difference stationary, while the weighted symmetric tau test (Pantula et al, 1994) for single time-series indicates that the natural logarithm of average weekly earnings, manufacturing price and trend GDP also have unit roots in levels but are first-difference stationary. ${ }^{7}$ Using Pedroni’s (1999) group ADF test for panel data, the null of no cointegration is rejected at the 1 percent level of significance. ${ }^{8}$ These results suggest that the error-correction mechanism and the error term from (8) are both stationary, so that inferences resulting from estimation of the model are not spurious.

\footnotetext{
${ }^{6}$ Because price indices transformed into natural logarithms can be represented as an unknown number plus the natural logarithm of the true price, only the value of the constant term is affected by arbitrary variations in this unknown number.

${ }^{7}$ The IPS test of industry materials price in levels rejects a unit root at the 5 percent level of significance. However, Levin and Lin tests do not reject the existence of a unit root in levels and the IPS test of industry materials price in first differences strongly rejects a unit root. Therefore, industry materials price is taken to be first-difference stationary.

${ }^{8}$ Note that this test is tentative as it does not include the cross-industry constraints of later estimation.
} 
$\underline{\text { Table } 1}$

Tests for non-stationarity of series in natural logarithm form

\begin{tabular}{cccc}
\hline Variable & Level & First Difference & Test Type \\
\hline$p_{d t}$ & 1.19 & $-6.61^{* *}$ & IPS \\
$m p_{d t}$ & $-2.28 *$ & $-11.28^{* *}$ & IPS \\
$i m p_{d t}$ & -1.16 & $-15.25^{* *}$ & IPS \\
$w_{t}$ & $0.81[7]$ & $-5.68^{* *}[2]$ & WS \\
$p_{t}$ & $0.46[5]$ & $-2.59^{*}[3]$ & WS \\
$y_{t}$ & $-0.01[5]$ & $-2.89^{*}[5]$ & WS \\
cointegration & $-2.52^{* *}$ & & Group ADF \\
\hline
\end{tabular}

IPS indicates Im, Pesaran and Shin (2003) test for unit roots in panel data.

WS indicates Pantula et al (1994) weighted symmetric tau test for unit roots in single time series.

Group ADF indicates Pedroni (1999) test for cointegration in panel data.

For each test the null hypothesis is non-stationarity. The panel data test statistics are $\mathrm{z}$ distributed under the null and all panel tests have a maximum eight lags and no time trend. WS tests have no time trend and the lag lengths are determined by the Akaike Information Criteria, with the lag lengths shown in brackets.

** indicates significant at the 1 percent level for a one-tailed test.

* indicates significant at the 5 percent level for a one-tailed test.

\section{Results}

The model is estimated using non-linear seemingly unrelated regression (SUR) while constraining the coefficients in the industry speed of price adjustment to be the same for all industries. Although this is a one-stage procedure, pre-testing is carried out in order to determine the appropriate short-run dynamics for the regression. Patterson (2000) shows that long-run parameter estimates may be biased for finite series when the short-run dynamics are excluded, while Kremers et al (1992) show that hypothesis tests of the speed of adjustment are likely to have low power. 
Therefore, the error-correction model is estimated individually for each industry by non-linear least squares, allowing for up to two lags in the short-run difference variables. These lags are successively eliminated when the estimated coefficients are insignificant based on $\mathrm{t}$ and $\mathrm{F}$ tests, until the final short-run dynamic structure is obtained for each industry. ${ }^{9}$

Table 2 presents the regression results for $(10) .{ }^{10}$ For comparison, an industry and time invariant speed of price adjustment is also estimated. The t-statistics presented in this table are computed from heteroscedastic-consistent standard errors. It can be seen that the estimate of the speed of price adjustment in column (1) is 0.17 and significantly different from zero. Kremers et al (1992) find that the distribution for the speed of adjustment in a single equation is somewhere between normal and Dickey-Fuller. Given the large t-statistic (8.16), the inference is the same for both distributions (the asymptotic Dickey-Fuller critical value at the 5 percent level is 4.98).

Also, the results provide support for the theoretical model when firms have economies of scale with regard to price adjustment costs. It is shown in Table 2 that $S I Z 4_{d}$ is significantly positive at the 10 percent level, while $C R 4_{d}$ is significantly negative at the 1 percent level. This latter result conforms to the findings in Dixon (1983), Bedrossian and Moschos (1988), Weiss (1993) and Shaanan and Feinberg (1995).

To get a feel for the impact of firm size and industry concentration on the industry speed of price adjustment we can multiply actual values by the coefficient estimates. Metal Product Manufacturing (28) has the largest average turnover for the

\footnotetext{
${ }^{9}$ The details can be obtained from the authors.

${ }^{10}$ Estimates of the parameters in (8) and (9) are not presented here, but these can be obtained from the authors upon request. The authors also estimate (10) using long and short-run variables in levels and find little qualitative difference from the results presented in Table 2.
} 
biggest four firms at $\$ 3.1$ billion in 1993-94 and this increases the industry speed of price adjustment by 0.12. Non-Metallic Mineral Product Manufacturing (26) has the highest industry concentration at 0.53 and this reduces the speed of price adjustment by 0.22 .

$\underline{\text { Table } 2}$

SUR estimation results for the industry speed of price adjustment $\left(\lambda_{d}\right)$ when it is treated as a constant and as a function of cross-sectional variables

$\begin{array}{lcc}\text { Variable } & (1) & (2) \\ & & \\ \text { Constant } & 0.17^{* *} & 0.21^{* *} \\ & (8.16) & (4.47) \\ & & \\ C R 4_{d} & & -0.42^{* *} \\ & & (-2.66) \\ S I Z 4_{d} & & 0.04^{\#} \\ & & (1.91)\end{array}$

t-statistics computed from heteroscedastic-consistent standard errors are in parentheses.

** indicates significant at the 1 percent level for a two-tailed t test.

*indicates significant at the 5 percent level for a two-tailed t test.

\# indicates significant at the 10 percent level for a two-tailed t test.

Thus far we have assumed that the industry speed of price adjustment is a function of cross-sectional variables. However, structural variables that change across industry and time, and cyclical variables that change across time, may also affect the industry speed of price adjustment through their influence on the elasticity of demand. We treat import share $\left(M_{d t}\right)$ as a structural variable that varies across time. ${ }^{11} \mathrm{~A}$ number of studies have estimated the impact of import share on the speed of price adjustment (for example, see Dixon, 1983; Kraft, 1995; Shannan and Feinberg, 1995).

\footnotetext{
${ }^{11}$ The recent opening up of the Australian economy has seen rapid import penetration in a number of manufacturing industries. In the 10 years from 1990 to 2000, import penetration increased at an average annual rate of 4.1 percent for All Manufacturing, 5.1 percent for Textile, Clothing, Footwear and Leather, and 7.2 percent for Metal Products (Productivity Commission, 2003).
} 
Dixon (1983) suggests that domestic industry concentration needs to be modified with the inclusion of import share in the estimating equation in order to represent the true degree of concentration with foreign competitors in the market. In a formal model with small country assumptions, Bloch (1994) shows that higher import shares reduce the elasticity of price conjectures, thus making demand more elastic. In light of our model, we therefore expect higher import share to increase the speed of price adjustment.

The influence of the cycle on the elasticity of demand at an industry level is ambiguous. In boom times, increased levels of demand may increase market power for individual firms. However, anticipation of larger profits may lead to a reduction in co-operation amongst existing firms and to other firms entering the market, resulting in more elastic demand. Therefore, the impact of the cycle on industry speed of price adjustment is to be empirically determined. The cycle variable employed here is the growth in trend real GDP $\left(T G_{t}\right)^{12}$.

The impact of import share and the cycle on the industry speed of price adjustment are estimated in turn and the results are shown in Tables 3. In order to indicate if there has been a structural change in the industry speed of price adjustment emanating from an unknown source, the impact of a dummy variable (Dummy) that is zero from 1985:3 to 1990:4 and one from 1991:1 to 2002:3 is also estimated. In regressions (1), (2) and (3), Dummy, $M_{d t}$ and $T G_{t}$ are each insignificantly different from zero. However, when these variables are all included together in regression (4), Dummy is significantly positive at the one percent level and $T G_{t}$ is significantly negative at the five percent level, while $M_{d t}$ is insignificantly different from zero. These results suggest that there is an unexplained speeding up of industry price

\footnotetext{
${ }^{12}$ Rosenbaum and Sukharomana (2001) find that a cycle dummy based on a deterministic trend is negatively related to market power in the US Portland cement industry.
} 
adjustment in the 1990s via the dummy variable, but that the magnitude of the change is too small (0.003) to be economically irrelevant. Also, the negative sign on $T G_{t}$ is consistent with higher growth levels leading to greater market power for firms and this slowing industry speed of price adjustment.

\section{Table 3}

SUR estimation results for the industry speed of price adjustment when it is a function of cross-sectional and time variables.

\begin{tabular}{|c|c|c|c|c|c|}
\hline Variable & (1) & (2) & (3) & (4) & (5) \\
\hline Constant & $\begin{array}{c}0.21^{* *} \\
(4.57)\end{array}$ & $\begin{array}{c}0.26 * * \\
(5.31)\end{array}$ & $\begin{array}{c}0.24^{* *} \\
(5.35)\end{array}$ & $\begin{array}{c}0.26 * * \\
(6.85)\end{array}$ & $\begin{array}{c}0.29 * * \\
(7.49)\end{array}$ \\
\hline$C R 4_{d}$ & $\begin{array}{c}-0.46 * * \\
(-4.52)\end{array}$ & $\begin{array}{c}-0.49 * * \\
(-3.27)\end{array}$ & $\begin{array}{c}-0.44 * * \\
(-4.60)\end{array}$ & $\begin{array}{l}-0.53 * * \\
(-10.17)\end{array}$ & $\begin{array}{c}-0.59 * * \\
(-9.44)\end{array}$ \\
\hline$S I Z 4_{d}$ & $\begin{array}{l}0.05 * \\
(2.28)\end{array}$ & $\begin{array}{c}0.03 \\
(1.32)\end{array}$ & $\begin{array}{c}0.04 \\
(1.95)\end{array}$ & $\begin{array}{l}0.03 * \\
(2.01)\end{array}$ & $\begin{array}{l}0.03^{*} \\
(2.07)\end{array}$ \\
\hline Dummy & $\begin{array}{l}-0.001 \\
(-0.91)\end{array}$ & & & $\begin{array}{c}0.003 * * \\
(4.44)\end{array}$ & $\begin{array}{c}0.003 * * \\
(3.92)\end{array}$ \\
\hline$M_{d t}$ & & $\begin{array}{c}0.02 \\
(1.63)\end{array}$ & & $\begin{array}{l}-0.001 \\
(-0.28)\end{array}$ & $\begin{array}{c}-0.10 * * \\
(-2.86)\end{array}$ \\
\hline$T G_{t}$ & & & $\begin{array}{c}-2.36 \\
(-1.59)\end{array}$ & $\begin{array}{l}-1.86^{*} \\
(-2.30)\end{array}$ & $\begin{array}{l}-2.05 * \\
(-2.40)\end{array}$ \\
\hline$M_{d t} * C R 4_{d}$ & & & & & $\begin{array}{c}0.25 * * \\
(2.74)\end{array}$ \\
\hline
\end{tabular}

t-statistics computed from heteroscedastic-consistent standard errors are in parentheses.

** indicates significant at the 1 percent level for a two-tailed t test.

*indicates significant at the 5 percent level for a two-tailed $t$ test.

\# indicates significant at the 10 percent level for a two-tailed t test.

In order to capture the degree to which industry concentration is modified by openness to import competition, industry concentration multiplied by import share $\left(M_{d t} * C R 4_{d}\right)$ and is added to regression (5). While all other coefficient estimates are of a similar value and significance to regression (4), $M_{d t}$ is negative and significantly 
different to zero and $M_{d t} * C R 4_{d}$ is positive and significantly different to zero. These results imply that import share reduces the impact of industry concentration on the industry speed of price adjustment when the level of industry concentration is high. However, import share slows the industry speed of price adjustment when industry concentration is low. One explanation for this result is that import competition may disrupt firm price adjustment toward their target levels in low concentration industries (see Shannan and Feinberg, 1995).

It can be seen from Table 3 that the inclusion of time variables only has a minor effect on $S I Z 4_{d}$ (ranging from 0.03 to 0.05 ), $C R 4_{d}$ (ranging from -0.44 to 0.59 ) and the constant (ranging from 0.21 to 0.29 ), although $C R 4_{d}$ and the constant are raised for regressions (4) and (5). These results also suggest that industry concentration and the size of firms within an industry are important determinants of the cross-sectional variation in the industry speed of price adjustment.

The implied speed of price adjustment for an industry in any one time period is obtained by multiplying the coefficient estimates for regression (5) in Table 3 by the relevant industry variable values and summing. Table 4 shows the implied speed of price adjustment for each industry averaged over the whole period, averaged over the period $1985: 3$ to $1990: 4$ and averaged over the period 1991:1 to $2002: 3$. It is obvious that the average speed of price adjustment in 1985:3 to 1990:4 is virtually the same as in 1991:1 to 2002:3 for every industry. This supports Dwyer and Leong's (2001) finding at the aggregate level, that the 1990s slow down in inflation has not been caused by a shift in the speed at which firms adjust their prices. 
$\underline{\text { Table } 4}$

Implied speed of price adjustment for nine ANZSIC two-digit industries calculated from the regression (5) results presented in Table 3.

\begin{tabular}{|c|c|c|c|c|c|}
\hline Industry & $\begin{array}{c}\text { Average } \\
(1985: 3- \\
2002: 3 \\
\end{array}$ & $\begin{array}{c}\text { ndustry } S_{f} \\
\text { Average } \\
\text { (1985:3- } \\
\text { 1990:4 } \\
\end{array}$ & $\begin{array}{l}\text { eed of Pric } \\
\text { Average } \\
\text { (1991:1- } \\
\text { 2002:3 } \\
\end{array}$ & Adjustmen & Maximum \\
\hline $\begin{array}{l}\text { (21) Food, Beverage } \\
\text { and Tobacco }\end{array}$ & 0.23 & 0.23 & 0.23 & 0.26 & 0.22 \\
\hline $\begin{array}{l}\text { (22) Textile, Clothing, } \\
\text { Footwear and Leather }\end{array}$ & 0.17 & 0.18 & 0.17 & 0.20 & 0.16 \\
\hline $\begin{array}{l}\text { (23) Wood and } \\
\text { Paper Products }\end{array}$ & 0.09 & 0.09 & 0.09 & 0.11 & 0.07 \\
\hline $\begin{array}{l}\text { (24) Printing, } \\
\text { Publishing and }\end{array}$ & 0.14 & 0.14 & 0.14 & 0.17 & 0.13 \\
\hline $\begin{array}{l}\text { Recorded Media } \\
\text { (25) Petroleum, Coal, } \\
\text { Chemical and }\end{array}$ & 0.16 & 0.16 & 0.16 & 0.18 & 0.14 \\
\hline $\begin{array}{l}\text { Associated Products } \\
\text { (26) Non-Metallic } \\
\text { Mineral Products }\end{array}$ & 0.002 & 0.001 & 0.002 & 0.02 & -0.02 \\
\hline (27) Metal Products & 0.16 & 0.16 & 0.16 & 0.18 & 0.14 \\
\hline $\begin{array}{l}\text { (28) Machinery } \\
\text { and Equipment }\end{array}$ & 0.18 & 0.18 & 0.18 & 0.20 & 0.17 \\
\hline $\begin{array}{l}\text { (29) Other } \\
\text { Manufacturing }\end{array}$ & 0.21 & 0.21 & 0.21 & 0.23 & 0.19 \\
\hline
\end{tabular}

Table 4 also shows the maximum and minimum implied speed of price adjustment for each industry. The range of values from minimum to maximum is either 0.03 or 0.04 . Such a small range suggests that the industry speed of price adjustment is stable over the cycle. Greater variation in the industry speed of price adjustment seems to occur across industries with the maximum and minimum average values across the period being, respectively, 0.23 for (21) Food, Beverage and Tobacco and 0.002 for (26) Non-Metallic Mineral Products.

The average value of the speed of price adjustment across all industries is 0.15 (calculated from Table 4), which is slow when compared to a number of overseas 
industry studies (for example, see Bedrossian and Moschos (1988) for Greece and Kardasz and Stollery (1988) for Canada). Using the median lag formula $\left[\ln (0.5) / \ln \left(1-\lambda_{d}\right)\right]$, this equates to half of the impact in industry price from a disturbance to the long-run relationship taking 4.3 quarters to work itself out on average. ${ }^{13}$ However, Dwyer and Leong's (2001) estimate for the speed of price adjustment for Australian consumer prices is 0.07 , which suggests an even longer median lag of 9.6 quarters (similar estimates for Australian consumer prices are obtained by Stone et al; 2005). This difference may be due to the level of aggregation and differences in sectors of the economy.

\section{Implications and conclusions}

The empirical results presented in this paper suggest that the industry speed of price adjustment to its long run level is quite slow and is determined in the most part by structural variables that do not change rapidly over time. If these findings can be extended to other sectors of the economy, then policy makers can be reasonably confident that the aggregate speed of price adjustment will remain slow and stable in the face of monetary, fiscal and external shocks.

Evidence suggests that sticky prices may already be the Australian Reserve Bank’s (RBA) working assumption, as witnessed by their response to the exchange rate overshooting that occurred in 2001-02. At this time, United States dollars per Australian dollar fell sharply to 0.5 before rebounding to 0.75 in late 2003. In response, the RBA decided not to increase interest rates in order to prevent domestic inflation that could occur through import price increases. This decision was vindicated by the ensuing stable inflation rate.

\footnotetext{
${ }^{13}$ This median lag formula is appropriate for the partial adjustment model, so the values derived here
} 
Apart from the stability and speed of price adjustment, this paper also examines its causes. The results suggest that industry concentration reduces the industry speed of price adjustment, while it is increased by average firm size. An intuitive explanation is that large firms have scale economies with regard to price adjustment costs and less cause to slow their speed of price adjustment, while firms with market power can offset price adjustment costs by slowing the speed of price adjustment. Finally, the results also imply that there is little evidence of structural change to industry speeds of price adjustment at the beginning of the 1990s and that the cycle has an influence that is measurable but small.

\section{Data Appendix}

All manufacturing industry data are at the two-digit ANZSIC level, while all time series data are quarterly and for the period 1985:3 to 2002:3.

$p_{d t}$ - Price index of articles produced by domestic manufacturing industries (sourced to ABS Producer Price Indexes; 6427.0, Table 11). In particular cases, a weighted average of subgroup price indices is taken to create two-digit price indices. Weights are the combined turnover shares for subgroups in 1990-91 (sourced to ABS Manufacturing Industry; 8221.0). The relevant subgroups are: 221-222 and 223-226; 231-232 and 233; 251-252 and 253-254 and 255-256; 271-273 and 274-276; 281-282 and 283-286.

$m p_{d t}$ - Price index of material inputs by domestic manufacturing industries (sourced to ABS Producer Price Indexes; 6427.0, Table 14 [and 6411.0 prior to 1989:3 for industries 23, 24 and 25]). In particular cases, a weighted average of subgroup price indices is taken to create two-digit price indices. Weights are the 
combined turnover shares for subgroups in 1990-91 (sourced to ABS Manufacturing Industry; 8221.0). The relevant subgroups are: 221-222 and 223-224 and 225; 231232 and 233; 251-252 and 253-254 and 255-256; 271-273 and 274-276; 281-282 and 283-286.

$i m p_{d t}$ - Price index of manufactured imports (sourced to ABS International Trade Price Indexes, Australia; 6457.0, Table 15 [and 6414.0 prior to 1991:2 for industries 22, 23, 24, 25, 28 and 29]). In order to get two-digit import price indices, weighted averages of the following subgroups are taken: 221-222 and 223-226; 271273 and 274-276; 281-282 and 283-286. Weights are shares of total imports in 1991 (sourced to Industry Commission, 1995. Manufacturing industry and international trade data, 1968-69 to 1992-93).

$w_{t}-$ Average weekly total earnings for total persons in manufacturing (sourced to ABS Average Weekly Earnings; 6302.0, Table 10i).

$p m_{t}$ - Price index of articles produced by manufacturing industries (sourced to ABS Producer Price Indexes; 6427.0; Table 10).

$y_{t}-$ Trend chain volume measure of GDP (sourced to ABS Australian National Accounts; 5206.0, Table 14).

$C R 4_{d}-$ Ratio of turnover for the four largest domestic firms to the value of total industry turnover in the year 1993-94 (sourced to ABS Manufacturing Industry, 8221.0).

$S I Z 4_{d}$ - Average turnover for the four largest domestic firms within the industry (\$billions) in the year 1993-94 (sourced to ABS Manufacturing Industry, 8221.0).

$M_{d t}$ - Industry annual import share of apparent domestic consumption. Imports sourced from ABS 5368.0 (Table 17), exports are sourced from ABS 5368.0 (Table 
14) and sales are taken from ABS 5676.0 (Table 21). Prior to 1989, import share is obtained from Industry Commission (1995).

$A G_{t}$ - Average annual growth rate in chain volume measure of GDP, divided by four (sourced from ABS 5206.0, Table 3).

$T G_{t}-$ Growth rate in trend chain volume measure of GDP, divided by four (sourced from ABS 5206.0, Table 14).

$O G_{t}-$ Output gap is equal to the proportional difference between a seasonally adjusted chain volume measure of GDP and a trend chain volume measure of GDP (sourced from ABS 5206.0 (Table 4) and ABS 5206.0 (Table 14)). 


\section{References}

Apel, M., Friberg, R., Hallsten, K., 2005. Microfoundations of macroeconomic price adjustment: survey evidence from Swedish firms. Journal of Money, Credit and Banking 37, 314-338.

Bedrossian, A., Moschos, D., 1988. Industrial structure, concentration and the speed of price adjustment. Journal of Industrial Economics 26, 459-475.

Bhattacharya, M., Bloch, H., 2000. The dynamics of industrial concentration in Australian manufacturing. International Journal of Industrial Organization, 18, 1181-1199.

Bloch, H., Olive, M., 2003. Does openness mean that domestic prices are determined abroad? In Bloch, H. (ed). Growth and Development in the Global Economy. Edward Elgar, Cheltenham, UK.

Bloch, H., Olive, M., 1999. Cyclical and competitive influences on pricing in Australian Manufacturing. Economic Record 75, 268-79.

Bloch, H., 1994. The impact of foreign and domestic competition on pricing in Australian manufacturing. In Johnson, M., Kriesler, P., Owen, A. (eds). Issues in Australian Economics. Allen and Unwin, North Sydney.

Bloch, H., 1992. Pricing in Australian manufacturing. Economic Record 68, 365-376.

Dixon, R., 1987. The role and consequence of structural change in recent Australian economic growth. University of Melbourne Discussion Paper, No 162.

Dixon, R., 1983. Industry structure and the speed of price adjustments. Journal of Industrial Economics 32, 25-27.

Domberger, S., 1983. Industrial Structure, Pricing and Inflation. Robinson and Company, Oxford, UK.

Dornbusch, R., Bodman, P., Crosby, M., Fischer, S., Startz, R., 2002. 
Macroeconomics. McGraw-Hill, Australia, Roseville.

Dwyer, J., Leong, K., 2001. Changes in the determination of inflation in Australia. Reserve Bank of Australia Research Discussion Paper 2001-02.

Im, K.S., Pesaran, M.H., Shin, Y., 2003. Testing of unit roots in heterogeneous panels. Journal of Econometrics 115, 53-74.

Kardasz, Stanley W. and Stollery, Kenneth (1988), "Price Formation in Canadian Manufacturing Industries”, Applied Economics, 20, 473-483.

Kasa, K., 1998. Identifying the source of dynamics in disaggregated import data. Journal of Applied Econometrics 13, 305-320.

Kraft, K., 1995. Determinants of price adjustment. Applied Economics 27, 501-507.

Kremers, J.J.M., Ericsson, N.R., Dolado, J.J., 1992. The power of cointegration tests. Oxford Bulletin of Economics and Statistics 54, 325-348.

Lindbeck, A., Snower, D.J., 2001. Insiders versus outsiders. Journal of Economic Perspectives 15, 165-188.

Lipczynski, J., Wilson, J., Goddard, J., 2005. Industrial Organization: Competition, Strategy, Policy (2 ${ }^{\text {nd }}$ Ed.). Prentice Hall, Harlow, England.

Martin, C., 1993. Price adjustment and market structure. Economics Letters 41, 139143.

Nickell, S., 1985. Error correction, partial adjustment and all that: an expository note. Oxford Bulletin of Economics and Statistics 47, 119-129.

O’Regan, J., Wilkinson, J., 1997. Internationalisation and pricing behaviour: some evidence for Australia. Reserve Bank of Australia Research Discussion Paper 9707.

Pantula, S., Gonzalez-Farias, G., Fuller, W.A., 1994. A comparison of unit-root test criteria. Journal of Business and Economic Statistics 12, 449-459. 
Patterson, 2000.An Introduction to Applied Econometrics: A Time Series Approach. Macmillan, Houndmills, UK.

Pedroni, P., 1999. Critical values for cointegration tests in heterogeneous panels with multiple regressors. Oxford Bulletin of Economics and Statistics 61, 653-670.

Productivity Commission, 2003. Trends in Australian manufacturing. Commission Research Paper, AusInfo, Canberra.

Reserve Bank of Australia, 2004. Chart Pack. http://www.rba.gov.au/ChartPack/index.html

Roberts, J.M., 1992. Evidence on price adjustment costs in U.S. manufacturing industry. Economic Enquiry 30, 399-417.

Rosenbaum, D.I., Sukharomana, S., 2001. Oligopolistic pricing over the deterministic market demand cycle: some evidence from the US Portland cement industry. International Journal of Industrial Organization 19, 863-884.

Rotemberg, J.J., 1982a. Sticky prices in the United States. Journal of Political Economy 90, 1187-1211.

Rotemberg, J.J., 1982b. Monopolistic price adjustment and aggregate output. Review of Economic Studies 49, 517-531.

Sawyer, M.C., 1982. On the specification of structure performance relationships. European Economic Review 17, 295-306.

Shaanan, J., Feinberg, R.M., 1995. Dynamic competition and price adjustments. Southern Economic Journal 62, 460-466.

Stone, A., Wheatly, T., Wilkinson, L., 2005. A small model of the Australian macroeconomy: an update. Reserve Bank of Australia Research Discussion Paper 2005-11.

Taylor, J.B., 2000. Low inflation, pass-through, and the pricing power of firms. 
European Economic Review 44, 1389-1408.

Weiss, C., 1993. Price inertia and market structure: empirical evidence from Austrian manufacturing. Applied Economics 25, 1175-1186. 